\title{
Changes in Heart Rate Variability and Glycosylated Hemoglobin in Prediabetics and Type 2 Diabetes Mellitus
}

\author{
Mishra $\mathrm{AK}^{1^{*}}$, Jha $\mathrm{RK}^{2}$, Kapoor $\mathrm{BK}^{2}$
}

${ }^{1}$ Department of Medicine, Bhakatpur District Hospital, Bhakatpur, Nepal

${ }^{2}$ Department of Physiology, Kathmandu University School of Medical Sciences, Dhulikhel, Kavre

\section{DOI Name}

http://dx.doi.org/10.3126/jaim.v5i1.17066

\section{Keywords}

Cardiac autonomic neuropathy, Diabetes mellitus, Heart rate variability

\section{Citation}

Mishra AK, Jha RK, Kapoor BK. Changes in heart rate varibalitiyy and glycosylated hemoglobin in prediabetics and type 2 diabetes mellitus. Journal of Advances in Internal Medicine 2016;05(01):15-18.

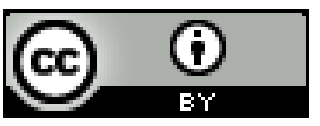

This work is licensed under a Creative Commons Attribution 3.0 Unported License.

\section{ABSTRACT \\ Background}

People with diabetes mellitus (DM) suffer from cardiac autonomic neuropathy (CAN), this may remain subclinical and reduced heart rate variability (HRV) is noticed as its early indicator.

\section{Objective}

The present study was undertaken to investigate the changes in heart rate variability and glycosylated hemoglobin ( $\mathrm{HbA1C}$ ) in (i) pre-diabetics, (ii) diabetics, (iii) non-diabetic subjects.

\section{Methods}

The present study enrolled 30 patients, diagnosed with type $2 \mathrm{DM}$ and 30 prediabetic subjects aged between 30-60 years and compared with its aged matched healthy controls. In HRV, Time Domain (TD) parameters used were: SDNN, rMSSD, NN50 and pNN50\%; and Frequency Domain (FD) parameters were: low frequency (LF), high frequency (HF) and LF/HF ratio. Glycosylated $\mathrm{Hb}$ and random blood sugar were measured.

\section{Results}

In HRV, though the time domain measures that reflects parasympathetic activity decreased was insignificant in the cases, the FD parameters such as LF reflecting activities of both division of ANS and HF reflecting only parasympathetic activity were found significantly reduced in diabetes and then control, whereas LF/HF ratio was increased only in diabetic patient $(p<0.001)$ indicating sympathovagal imbalance. Rise in $\mathrm{HbA1C}$ was insignificant in prediabetic compared to control, which was observed significant only in diabetic $(p<0.001)$ patients.

\section{Conclusion}

Findings of the present study suggest that though $\mathrm{HbA1c}$ is an indicator of sustained hyperglycemia for monitoring glycemic level, even before its significant rise in plasma, alteration of sympatho-vagal balance over heart begins early in the disease process of diabetes.

\section{INTRODUCTION}

Heart rate variability is a measurement of time interval between consecutive heart beats, measured in milliseconds. ${ }^{1}$ HRV gives information about the sympathetic-parasympathetic autonomic balance. ${ }^{2}$

Diabetes mellitus (DM) is a debilitating disease which affects several million people worldwide. There is a long asymptomatic prediabetic stage before the development of diabetes. For development of diabetes, basic pathological defects i.e. insulin resistance and $\beta$ cell secretory defect have to coexist. ${ }^{3}$

Neuropathy associated with DM is characterized by alterations in small nerve fibers, leading to reduction in parameters of HRV. ${ }^{2}$ People with diabetes mellitus (DM) suffer from cardiac autonomic neuropathy (CAN), this may remain subclinical

\footnotetext{
* Corresponding author Abadhesh Kumar Mishra Department of Medicine Bhakatpur District Hospital Bhakatpur, Nepal
} 
and reduced heart rate variability (HRV) is noticed as its early indicator. ${ }^{4}$ Thus the present study was aimed to investigate the changes in heart rate variability and glycosylated hemoglobin (HbA1C) in (i) pre-diabetics, (ii) diabetic, (iii) non-diabetic subjects.

\section{METHODS}

The study was conducted in 30 patients, diagnosed with type 2 DM and 30 prediabetic subjects aged between 30-60 years and compared with its aged matched healthy control in the Department of Internal Medicine, Dhulikhel Hospital. The patients were newly diagnosed as well as follow up cases. The prediabetic as well as diabetic patients were chosen based on American diabetic Association (ADA) ${ }^{5}$ criteria given in Table 1.

After obtaining written consent the anthropometric measurement such as height, weight, was taken and body mass index (BMI) was calculated.

After anthropometric measurement, the subject was asked to take rest for 15 minutes in supine position. In the mean time, ECG electrodes were applied on the both upper limbs and sphygmomanometer was tied on the arm. The basal blood pressure and heart rare was recorded. Then the HRV data was recorded for $5 \mathrm{~min}$ at spontaneous respiration.

Table 1: Study group and their criteria

\begin{tabular}{|l|l|l|}
\hline Condition & FPG $(\mathrm{mg} / \mathrm{dl})$ & OGTT $(\mathrm{mg} / \mathrm{dl})$ \\
\hline Control & $<110$ & $<140$ \\
\hline Prediabetic & $110-125$ & $140-199$ \\
\hline Diabetic & $\geq 126$ & $\geq 200$ \\
\hline
\end{tabular}

\section{STUDY DESIGN}

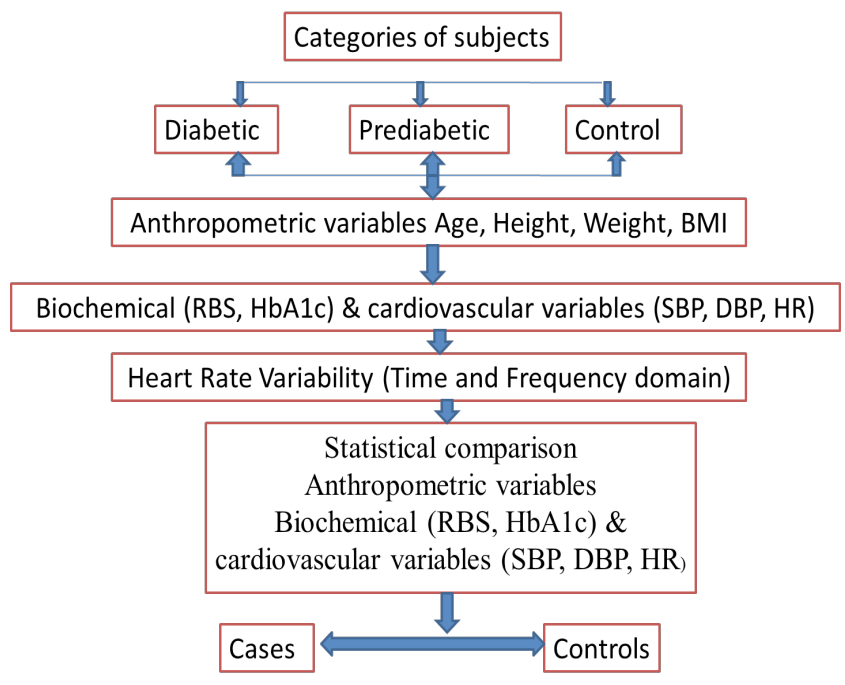

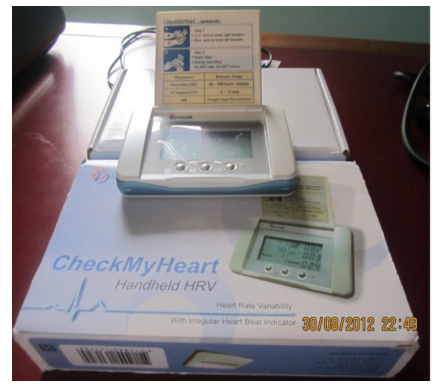

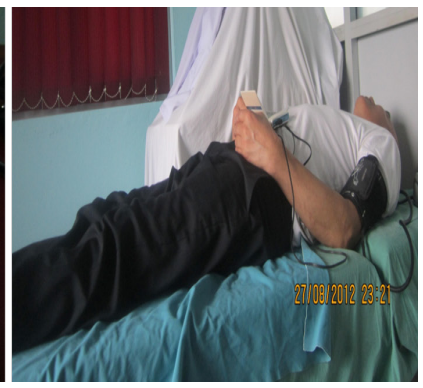

\section{RESULTS}

The study was carried out on 30 type 2 diabetic patients, 30 prediabetic (referred to as "cases") and 30 control subjects. Of all 90 subjects $52 \%$ were females. There were significant differences between the groups in term of their age, body mass index, random blood sugar and glycosylated hemoglobin (Table 2). Heart rate, diastolic blood pressure and systolic blood pressure were higher in prediabetic and diabetic subjects as compared to control are given in Table 3. All time domain variables of heart rate variability were decreased in prediabetic and diabetic patients as compared to controls. However these values were not significant (Table 4). In frequency domain variable, the low frequency (LF) and high frequency (HF) power were significantly reduced in prediabetic and diabetic as compared to control group whereas, LF/HF ratio was found significantly increased in diabetic patients than controls (Table 5).

Table 2: Anthropometric Variables

\begin{tabular}{|l|c|c|c|c|}
\hline Variables & Controls & Prediabetics & Diabetics & $\begin{array}{c}p \\
\text { Value }\end{array}$ \\
\hline Age (years) & $\begin{array}{c}44.26 \\
\pm 9.09\end{array}$ & $\begin{array}{c}45.76 \\
\pm 8.80\end{array}$ & $\begin{array}{c}51.53 \\
\pm 8.05^{*}\end{array}$ & 0.004 \\
& 23.58 & 24.87 & 26.38 & 0.013 \\
& \pm 4.15 & \pm 3.67 & $\pm 2.82^{*}$ & \\
\hline BMI (kg/m²) & 99.10 & 141.83 & 214.20 & 0 \\
& $\pm 26.20^{*}$ & $\pm 17.99^{*}$ & $\pm 72.45^{*}$ & \\
\hline HBS (mg/dl) & 4.70 & 4.83 & 8.37 & 0 \\
& \pm 0.48 & \pm 0.61 & $\pm 2.56^{*}$ & \\
\hline
\end{tabular}

Table 3: Cardiovascular Variables

\begin{tabular}{|c|c|c|c|c|}
\hline Variables & Controls & $\begin{array}{c}\text { Predia- } \\
\text { betics }\end{array}$ & Diabetics & $\begin{array}{c}p \\
\text { Value }\end{array}$ \\
\hline SBP $(\mathrm{mmHg})$ & $\begin{array}{c}118.27 \pm \\
14.6\end{array}$ & $\begin{array}{c}120.83 \pm \\
10.65^{*}\end{array}$ & $\begin{array}{c}128.80 \pm \\
11.62^{*}\end{array}$ & 0.004 \\
\hline DBP (mmHg) & $76.40 \pm$ & $78.03 \pm$ & $80.66 \pm$ & 0.216 \\
& 11.05 & 8.53 & 8.48 & \\
\hline HR (beats per & $73.63 \pm$ & $78.10 \pm$ & $80.93 \pm$ & 0.035 \\
minute) & 10.74 & 9.63 & $11.90^{*}$ & \\
\hline
\end{tabular}


Table 4: Time domain variables of HRV of cases and controls

\begin{tabular}{|c|c|c|c|c|}
\hline Variables & Controls & Prediabetics & Diabetics & $\begin{array}{c}p \\
\text { Value }\end{array}$ \\
\hline Mean & $\begin{array}{c}774.87 \pm \\
134.44\end{array}$ & $\begin{array}{c}754.18 \pm \\
101.48\end{array}$ & $\begin{array}{c}737.53 \pm \\
110.04\end{array}$ & 0.463 \\
& & & & \\
\hline SDNN & $47.31 \pm$ & $41.82 \pm$ & $32.36 \pm$ & 0.062 \\
(msec) & 32.77 & 17.87 & 20.04 & \\
\hline RMSSD (s) & $41.79 \pm$ & $38.25 \pm$ & $29.45 \pm$ & 0.13 \\
& 30.26 & 19.11 & 21.34 & \\
\hline NN50 & $33.50 \pm$ & $24.73 \pm$ & 21.33 & 0.169 \\
(count) & 32.36 & 23.85 & \pm 18.43 & \\
\hline pNN 50\% & $17.94 \pm$ & $17.79 \pm$ & $12.94 \pm$ & 0.297 \\
& 15.20 & 16.17 & 9.99 & \\
\hline
\end{tabular}

Table 5: Frequency domain variables of HRV of cases and control

\begin{tabular}{|c|c|c|c|c|}
\hline Variables & Controls & $\begin{array}{c}\text { Predia- } \\
\text { betics }\end{array}$ & Diabetics & $\begin{array}{c}p \\
\text { Value }\end{array}$ \\
\hline LF Power $\left(\mathrm{ms}^{2}\right)$ & $264.17 \pm$ & $129.63 \pm$ & $64.73 \pm$ & 0 \\
& 235.59 & $117.87^{*}$ & $42.76^{*}$ & \\
\hline HF Power $\left(\mathrm{ms}^{2}\right)$ & $399.97 \pm$ & $107.60 \pm$ & $57.17 \pm$ & 0 \\
& 338.05 & $73.80^{*}$ & $53.38^{*}$ & \\
\hline LF/HF ratio & $0.79 \pm$ & $1.27 \pm$ & $1.65 \pm$ & 0.003 \\
& 0.50 & 0.92 & $1.14^{*}$ & \\
\hline
\end{tabular}

\section{DISCUSSION}

In the present study heart rate variability, cardiovascular autonomic function test of diabetic patients was compared with prediabetic and control with the hypothesis that diabetes mellitus patients may show autonomic neuropathies. There were significant differences between control and diabetics in

\section{REFERENCES}

1. Acharya UR, Joseph KP, Kannathal N, Lim CM, Suri JS. Heart Rate Variability: a review. Med Bio Eng Comput. 2006; 44:1031-51

2. Task Force of the European Society of Cardiology and the North American Society of pacing and Electrophysiology. Heart Rate Variability. Standards of measurement, Physiological interpretation and Clinical use. European Heart Journal 1996. 17:354-381

3. Munjal YP. API Textbook of Medicine. $9^{\text {th }}$ edition. Jaypee Brothers Medical Publishers (P) Ltd. 2012 p:321-323. term of their body mass index,

random blood sugar, glycosylated hemoglobin. Our result was consistent with several studies. ${ }^{6,7,8}$ Shera et $\mathrm{al}^{6}$ reported that advanced age and obesity were associated with DM. Peterson et $\mathrm{al}^{9}$ showed the most significant factor correlating with incidence and progression of neuropathy is glycemic control. $\mathrm{HbA} 1 \mathrm{C}$ reflects status of glycemia.

Heart rate and systolic blood pressure were significantly higher in diabetic patient compared to prediabetic and control. Regensteiner et $\mathrm{al}^{10}$ showed that parasympathetic function was impaired in all patients with diabetic autonomic neuropathy and thus the cardio respiratory performance of diabetic patient is limited.

In HRV, the time domain parameters such as SDNN, rMSSD, an NN50 and pNN50\% measure that reflects parasympathetic activity was insignificantly decreased in the cases. The frequency domain parameters such as LF power and HF power were significantly reduced in diabetic and pre-diabetes than control, whereas LF/HF ratio was increased only in diabetic patient indicating sympathovagal imbalance.

Rise in $\mathrm{HbA} 1 \mathrm{C}$ was insignificant in prediabetic compared to control, which was observed significantly raised in diabetic patients. HbA1c is an indicator of sustained hyperglycemia for monitoring glycemic level, even before its significant rise in plasma, alteration of sympatho-vagal balance over heart begins early in the disease process of diabetes. ${ }^{11}$

\section{CONCLUSION}

Our study suggests that there are both sympathetic and parasympathetic dysfunctions, but from increased values of $\mathrm{LF} / \mathrm{HF}$ ratios it is inferred that there is more parasympathetic damage than sympathetic nerve damage. Parasympathetic damage occurs early in the disease process of diabetes due to axonal degeneration of longer vagal fibers caused by chronically elevated levels of blood glucose.
4. Vinik Al, Maser RE, Mitchell BD, Freeman R. Diabetic autonomic neuropathy. Diabetes Care 2003; 26:155379.

5. American Diabetes Association Expert Committee: Report of the Expert Committee. Diabetes Care.1997; 20:1183-97

6. Shera AS, Rafique G, Khawaja IA, Baqai S, Khan IA and King $\mathrm{H}$. Pakistan National Diabetes Survey prevalence of glucose intolerance and associated factors in North West at Frontier Province (NWFP) of Pakistan. J Pak med Assoc. 1999; 49(9):206-211. 
7. Dan L, Anthony SF, Dennis LK, Stephen LH, Larry J, Joseph L. Harrison's principles of Internal Medicine. $18^{\text {th }}$ edition. McGraw-Hill Companies, Inc. 2012

8. Kolterman OG, Gray RS, Griffin J, Bur-stein P, Insel J, Scarlett JA, et al. Receptor and postreceptor defects contribute to the insulin resistance in non insulin dependent diabetes mellitus. J Clin. Invest. 1981; 68:957-69

9. Peterson KP, Pavlovich JG, Goldstein D, Little R, England J, Peterson C. "What is hemoglobin A1c? An analysis of glycated hemoglobins by electrospray ionization mass spectrometry." Clin Chem. 1998; 44(9):1951-8

10. Regensteiner GJ. Type 2 diabetes mellitus and cardiovascular exercise performance. Reviews in Endocrinology Metabolic Disorder 2004; 5:269-276

11. Poanta L, Porojan M, Cerghizan A, Damian I, Dumitrascy DL. Heart rate variability and cardiovascular symptoms in patients with diabetes mellitus. Clujul Medical 2010; 83(4):636-640 